\title{
Analysis of used frying fats for the production of biodiesel
}

\author{
By M.V. Ruiz-Méndez*, S. Marmesat, A. Liotta and M.C. Dobarganes \\ Instituto de la Grasa (CSIC). Avda Padre García Tejero, 4. 41012 Sevilla \\ ${ }^{*}$ Corresponding author: mvruiz@ cica.es
}

\section{RESUMEN}

\section{Análisis de aceites y grasas de fritura para produc- ción de biodiese}

Los aceites y grasas de fritura, que se caracterizan por tener una calidad muy variable, se utilizan como material prima para la producción de biodiesel. El objetivo de este estudio es definir la utilidad de los métodos analíticos desarrollados para los aceites y grasas de fritura para caracterizar el biodiesel obtenido. Veinticuatro aceites de fritura procedentes del sector de restauración y de fritura doméstica fueron analizados antes y después de su transesterificación a ésteres metílicos de ácidos grasos. A partir de un análisis detallado mediante cromatografías de adsorción y exclusión, se deduce la importancia cuantitativa de los compuestos de polimerización tanto en el análisis directo de los aceites como en el análisis de los ésteres metílicos. Se encontró una excelente correlación lineal entre los compuestos polares y los ésteres metílicos polares $(R=0.9768)$. Se definen las interferencias de los compuestos formados durante la fritura en el análisis estándar para conocer la calidad del biodiesel y se propone la determinación de ésteres metílicos no polares como una buena alternativa a la determinación cromatográfica estándar.

PALABRAS - CLAVE: Aceites y grasas de fritura Análisis - Biodiesel - Compuestos polares - Esteres metílicos de ácidos grasos polares.

\section{SUMMARY}

\section{Analysis of used frying fats for biodiesel production}

Used frying fats and oils with highly variable and uncontrolled quality are used for the production of biodiesel The objective of this study was to define the analytical methods useful to obtaining information on the quality of the used frying oils as raw material for biodiesels as well as for the characterization of the biodiesels obtained from them. Twentyfour used frying oils from restaurants and domestic fryers were analyzed before and after transesterification to fatty acid methyl esters (FAME). From a detailed analysis of the samples by means of a combination of adsorption and size exclusion chromatography, the quantitative importance of polymeric compounds was deduced both from the direct analysis of the oils and from their FAME. Excellent linear correlation between polar compounds and polar FAME $(R=0.9768)$ was found. The possibilities of interferences from polar fatty acid in the standard method to determine the ester content are defined. Finally, determination of non-polar FAME by silica column is proposed as a good alternative to the gas chromatography method.

KEY-WORDS: Analysis - Biodiesel - Polar compounds Polar fatty acid methyl esters - Used frying oils.

\section{INTRODUCTION}

The base-catalyzed transesterification method is normally applied for biodiesel production. However, biodiesel produced from crude or refined oils is usually more expensive than petroleum-based diesel fuel. The recent concerns over sustainability, environmental issues, and raw material costs have made the use of used frying oils very attractive to the industry. In this respect, there have been a significant number of studies over the last decade with the aim of establishing the optimum conditions for biodiesel production using frying oils as raw material (Costa Neto et al., 2000; González Gómez et al., 2002; Leung, 2001; Al-Widyan et al., 2002; Supple et al., 2002; Tashtoush et al, 2004; Tomasevic and SilerMarinkovic, 2003; Zhang et al., 2003 a, b; Felizardo et al., 2006; Leung and Guo, 2006) or evaluating their performance as fuels (Mittelbach and Tritthart,1988; Al-Widyan and Al-Shyoukh, 2002; Zaher, 2003; Dorado et al.,2003; Ulusoy el al., 2004).

However, used frying oils from restaurants and food industries have a wide variety of qualities. During the frying process, the oil or fat is exposed to high temperatures in the presence of air and moisture. Under these conditions, they may undergo important changes due to hydrolytic, oxidative and thermal reactions resulting in the loss of quality of the frying oil and of the fried food. Changes in the main fat constituents are known, although it is not easy to foresee the rate of oil degradation due to the high number of variables involved in the frying process. Some of them are linked to the process itself, such as temperature, length of heating, continuous or discontinuous heating, turnover period, etc.; others to the food subjected to frying, i.e. lipid composition, main and minor constituents, etc.; or else to the fat or oil used e.g., unsaturation degree, initial quality and additives (Varela, 1985; Rodrigues Machado et al., 2007).

The new products formed during frying are polymers, dimers, oxidized triglycerides, as well as diglycerides and fatty acids (Dobarganes and Márquez-Ruiz, 2006). All these groups possess higher polarity than that corresponding to the initial triglycerides and can be easily quantified by means of adsorption chromatography (IUPAC, 1992). Thus, polar compound determination gives a good measurement of the total degradation of frying oils 
and, for this reason, it is not only the most accepted method in the evaluation of frying fats but also the limitation of the alteration of frying fats for human consumption in polar compound levels around $25 \%$ has been included in many official regulations (Firestone, 1996). Even more, analyses of used frying oils sampled by the Food Inspection Services in different countries have clearly demonstrated that the stated $25 \%$ polar compounds is overpassed in a significant number of used frying oils (Dobarganes and Márquez Ruiz, 1995a, 1995b, 1998).

Thus, used frying oils can be highly heterogeneous as compared to crude or refined oils. In general, it is found that crude oils have more than $95 \%$ of triglycerides + partial glycerides which would give more than $98 \%$ of fatty acid methyl esters (FAME) supposing that total tranesterification takes place. However, in the case of used frying oils, nonaltered FAME depends on the variable quality of the used frying oil (Dobarganes et al., 1984; Márquez Ruiz et al., 1995). At present, the quantification of the main groups of degradation compounds in used frying oils (Dobarganes et al, 1988, 2000) as well as in the FAME obtained after oil transesterification (Dobarganes et al, 1984; Márquez Ruiz et al., 1990) is not a difficult task and takes advantage of the two main properties differentiating the new compounds formed during frying from the initial TG, i.e. polarity and molecular weight (MW).

On the other hand, studies are necessary to clarify the new compounds present in used frying fats and oils as many of the new compounds formed during frying might interfere in the standard gas chromatographic determinations for evaluating the quality of biodiesel (European Standard, 2003a; 2003b).

The objective of this study was to define the analytical methods useful to obtaining information on the compounds present in used frying oils and to characterize the biodiesels obtained from them.

\section{EXPERIMENTAL PART}

\subsection{Samples}

Twenty-four used frying fats and oils were selected from those collected in restaurants and domestic fryers. Most of the samples had degradation levels close to that established for discarding used frying fats and oils for human consumption (25\% polar compounds)

\subsection{Analytical techniques}

Quantification of polar compounds and their distribution in oxidation, polymerization and hydrolytic compounds. Non-polar and polar fractions were separated from $1 \mathrm{~g}$ of oil sample by silica column chromatography $\left(20 \mathrm{~g}\right.$ silica- $\mathrm{H}_{2} \mathrm{O}, 95: 5$ $\mathrm{w} / \mathrm{w})$. Non-polar fraction containing unaltered TG was eluted with $150 \mathrm{~mL}$ of $\mathrm{n}$-hexane/diethyl ether $(90: 10, v / v)$. A second fraction, comprized of total polar compounds, was eluted with $150 \mathrm{~mL}$ of diethyl ether. Efficiency of the separation by adsorption chromatography was checked by TLC using hexane/diethyl ether/acetic acid (80:20:1, v/v/v) for development of plates and exposure to iodine vapor to reveal the spots. After evaporation of solvents, both fractions were weighed and dissolved in diisopropyl ether (25 $\mathrm{mg} / \mathrm{mL}$ ) for analysis by highperformance size exclusion chromatography (HPSEC), using a Rheodyne 7725i injector with 10$\mathrm{mL}$ sample loop, a Waters 510 pump (Waters, Milford, MA, USA), a HP 1037 A refractive index detector and a HP 3392 A integrator (HewlettPackard, Avondale, PA, USA). The separation was performed on two 100 and $500 \AA$ Ultrastyragel columns ( $25 \mathrm{~cm} \times 0.77 \mathrm{~cm}$ i.d.) packed with porous, highly cross linked styrene-divinylbenzene copolymers (film thickness: $10 \mathrm{~mm}$ ) (HewlettPackard, Avondale, PA, USA) connected in series, with tetrahydrofuran $(1 \mathrm{~mL} / \mathrm{min})$ as the mobile phase (Dobarganes et al., 2000). The groups of compounds separated were oligomeric triglycerides (OTG), dimeric triglycerides (DTG), oxidized monomeric TG (oxMTG), diglycerides (DG) and Fatty acids (FA) .

Quantification of polar fatty acid methyl esters and their distribution in oligomeric, dimeric and oxidized monomeric FAME. FAME were obtained by transesterification of oil samples with sodium methoxide and hydrochloric acid-methanol and subsequent recovery of methyl esters (Dobarganes et al., 1984). Methyl esters were separated by silica column chromatography, using hexane/diethyl ether $(95: 5)$ to elute a non-polar fraction and diethyl ether and methanol to obtain the polar fraction. Analysis of the polar fraction was performed by HPSEC, using the chromatographic conditions described above. The groups of compounds separated were oligomeric FAME (OFA), dimeric FAME (DFA) and oxidized monomeric FAME (OxMFA). The methodology was described in detail, including calibration and reproducibility data, in an earlier publication (Márquez-Ruiz et al., 1990).

Determination of fatty acid methyl esters was performed following the IUPAC Standard Method (IUPAC, 1992).

\section{RESULTS AND DISCUSSION}

Table 1 shows the evaluation of polar compounds and their distribution in the used frying oils selected. It is interesting to note that samples with the same percentage of total polar compounds showed different patterns of compound distribution. Thus, samples 8, 17, 21 and 22 had high contents of DG formed by hydrolysis while for the rest of the samples the compounds formed by oxidation and high temperature stood out. Such differences between samples are not unusual, considering that previous treatment is unknown and they may have been subject to very different procedures, especially in terms of frying temperature, frying 
Table 1

Quantitative determination of total polar compounds and their distribution in used frying oils

\begin{tabular}{|c|c|c|c|c|c|c|}
\hline \multirow[b]{2}{*}{ Sample } & \multicolumn{5}{|c|}{ Polar Compounds and distribution (\%) } & \multirow[b]{2}{*}{ FA } \\
\hline & Total & OTG & DTG & OxMTG & DG & \\
\hline 1 & 14,5 & 1,1 & 5,4 & 5,6 & 2,1 & 0,4 \\
\hline 2 & 17,4 & 2,1 & 7,7 & 5,9 & 1,2 & 0,5 \\
\hline 3 & 21,1 & 3,7 & 8,8 & 6,1 & 1,9 & 0,6 \\
\hline 4 & 22,8 & 3,3 & 7,3 & 8,9 & 3,1 & 0,3 \\
\hline 5 & 23,0 & 3,3 & 8,2 & 9,1 & 1,9 & 0,4 \\
\hline 6 & 23,1 & 4,0 & 9,2 & 6,8 & 2,5 & 0,6 \\
\hline 7 & 25,5 & 4,7 & 9,0 & 8,6 & 2,6 & 0,7 \\
\hline 8 & 25,5 & 2,7 & 7,1 & 8,6 & 6,9 & 0,1 \\
\hline 9 & 25,7 & 6,3 & 9,4 & 5,9 & 3,5 & 0,6 \\
\hline 10 & 26,4 & 5,5 & 8,9 & 6,4 & 5,1 & 0,5 \\
\hline 11 & 26,6 & 4,9 & 11,3 & 8,7 & 1,2 & 0,4 \\
\hline 12 & 27,5 & 6,2 & 9,8 & 7,7 & 3,4 & 0,4 \\
\hline 13 & 27,6 & 6,5 & 10,9 & 7,2 & 2,3 & 0,6 \\
\hline 14 & 27,6 & 3,7 & 7,3 & 9,4 & 6,2 & 1,1 \\
\hline 15 & 28,9 & 5,0 & 12,5 & 9,8 & 1,2 & 0,4 \\
\hline 16 & 30,8 & 5,9 & 9,8 & 11,5 & 3,2 & 0,4 \\
\hline 17 & 33,1 & 6,5 & 7,2 & 5,4 & 12,3 & 1,7 \\
\hline 18 & 35,2 & 8,6 & 14,0 & 10,8 & 1,4 & 0,4 \\
\hline 19 & 37,3 & 10,6 & 14,3 & 9,0 & 2,8 & 0,7 \\
\hline 20 & 39,2 & 10,5 & 13,6 & 9,8 & 4,5 & 0,9 \\
\hline 21 & 39,7 & 7,8 & 9,8 & 13,3 & 7,6 & 1,2 \\
\hline 22 & 43,5 & 12,1 & 13,9 & 10,0 & 6,9 & 0,7 \\
\hline 23 & 47,1 & 12,3 & 13,3 & 15,2 & 5,7 & 0,7 \\
\hline 24 & 49,7 & 21,1 & 13,5 & 10,9 & 3,4 & 0,8 \\
\hline
\end{tabular}

Abreviations: OTG, Olimeric triglycerides; DTG, dimeric triglycerides; OxMTG, oxidized monomeric triglycerides; Dg, diglycerides; and $F A$, fatty acids.

periods and total period of use. However, polymeric $\mathrm{TG}$, i.e. oligomeric + dimeric TG were the major constituents in all the samples as previously reported (Marmesat et al., 2007).

Table 2 summarizes the content of polar FAME and their distribution in oligomeric, dimeric and oxidized monomeric TG after tranesterification of the samples. In the second column the percentage of non-polar FAME has also been included. Figure 1 shows typical chromatograms obtained by exclusion chromatography of the two fractions previously obtained by silica column. As can be observed, non-

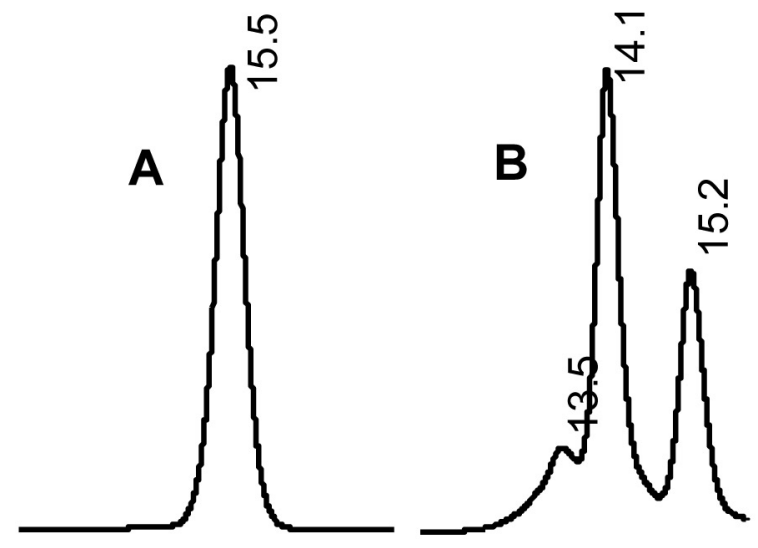

Figure 1

Partial high-performance size-exclusion chromatograms of non-polar fatty acid methyl esters (A) and polar fatty acid methyl esters (B). Retention times : $13.5 \mathrm{~min}$, Oligomeric

FAME; 14.1 min, Dimeric FAME; 15.2 min, oxidized monomeric FAME; 15.5 min, non-polar FAME. polar fraction is a single peak constituted by nonpolar FAME; while in the polar fraction three main groups of compounds were separated: oligomeric TG (MW > 900), dimeric TG (MW around 600) and oxidized monomeric TG (MW around 300).

As compared to the polar compounds in Table 1, the percentages of polar FAME were much lower as they only include the modified fatty acyl groups present in the TG molecules. Non-polar FAME include not only non-altered fatty acids from all the TG molecules but also those present in DG and fatty acids. Consequently, polar FAME is a direct measurement of thermoxidative degradation affecting unsaturated fatty acids. The results in Table 2 show that polymeric fatty acids (oligomeric + dimeric FAME) were the major compounds. Regression between polar compounds and polar FAME are presented in Figure 2 where the equation of the line as well as the high correlation coefficient found have been included. From the equation it can be deduced that a level of around $10 \%$ polar FAME is expected from samples around the level of used frying oil rejection ( $25 \%$ polar compounds).

It is important to note that analysis of polar FAME can be directly applied to biodiesels and that the results obtained would be parallel to those given in table 2 for used frying oils of a similar level of degradation. Thus, after biodiesel production polymeric FAME, i.e. oligomeric + dimeric FAME, as well as oxidized monomeric FAME are expected. Determination of non-polar FAME by adsorption chromatography is an interesting method due to its accuracy in obtaining information on the quality of 
Table 2

Quantitative determination of total polar fatty acid methyl esters and their distribution in used frying oils

\begin{tabular}{|c|c|c|c|c|c|}
\hline \multirow[b]{2}{*}{ Sample } & \multirow[b]{2}{*}{$\begin{array}{l}\text { Non-polar } \\
\text { FAME } \\
(\%)\end{array}$} & \multicolumn{4}{|c|}{ Polar FAME and their distribution (\%) } \\
\hline & & Total & $\begin{array}{l}\text { Oligomeric } \\
\text { FAME }\end{array}$ & $\begin{array}{l}\text { Dimeric } \\
\text { FAME }\end{array}$ & $\begin{array}{c}\text { Oxidized } \\
\text { monomeric } \\
\text { FAME }\end{array}$ \\
\hline 1 & 94,5 & 5,5 & 0,7 & 2,0 & 2,9 \\
\hline 2 & 93,2 & 6,8 & 0,9 & 3,3 & 2,6 \\
\hline 3 & 91,4 & 8,6 & 0,8 & 5,0 & 2,8 \\
\hline 4 & 91,3 & 8,7 & 1,2 & 4,0 & 3,6 \\
\hline 5 & 91,0 & 9,0 & 0,6 & 5,1 & 3,3 \\
\hline 6 & 90,9 & 9,1 & 0,8 & 5,1 & 3,3 \\
\hline 7 & 89,6 & 10,4 & 1,1 & 5,9 & 3,4 \\
\hline 8 & 90,6 & 9,4 & 0,5 & 5,2 & 3,7 \\
\hline 9 & 89,5 & 10,5 & 1,3 & 5,7 & 3,5 \\
\hline 10 & 89,2 & 10,8 & 0,7 & 6,7 & 3,4 \\
\hline 11 & 87,9 & 12,1 & 1,2 & 6,2 & 4,7 \\
\hline 12 & 89,3 & 10,7 & 1,1 & 6,2 & 3,4 \\
\hline 13 & 88,7 & 11,3 & 1,1 & 6,5 & 3,7 \\
\hline 14 & 90,3 & 9,7 & 0,5 & 5,5 & 3,8 \\
\hline 15 & 88,4 & 11,6 & 1,1 & 7,4 & 3,1 \\
\hline 16 & 86,3 & 13,7 & 2,7 & 6,2 & 4,7 \\
\hline 17 & 85,1 & 14,9 & 3,5 & 7,4 & 4,0 \\
\hline 18 & 82,7 & 17,3 & 3,8 & 8,6 & 4,9 \\
\hline 19 & 84,4 & 15,6 & 2,4 & 8,8 & 4,4 \\
\hline 20 & 84,9 & 15,1 & 2,9 & 8,4 & 3,8 \\
\hline 21 & 83,7 & 16,3 & 2,5 & 9,5 & 4,3 \\
\hline 22 & 83,7 & 16,3 & 4,1 & 8,3 & 3,9 \\
\hline 23 & 79,0 & 21,0 & 5,3 & 9,8 & 5,9 \\
\hline 24 & 77,0 & 23,0 & 6,1 & 10,3 & 6,6 \\
\hline
\end{tabular}

the biodiesel as an alternative to the standard method by gas chromatography.

On the other hand, as stated for animal fats and lauric oils (Schober et al., 2006), the standard method EN14103 by GC (European Standard, 2003b) may give misleading results depending on the level of polar FAME, as many compounds formed may elute between fatty acids ranging from C 12:0 and C 24:1. In this respect, even if polymeric FAME are the major compounds and they are non- eluted materials in FAME analysis by GC, oxidized fatty acid monomers are also important from a quantitative point of view and they elute in the GC analysis.

Separation and identification of the main structures in FAME from used frying fats indicate that compounds with molecular weight lower than or similar to that of the original fatty acids are present. Among the first group, the short-chain FAME, the short-chain n-oxo FAME and diacid

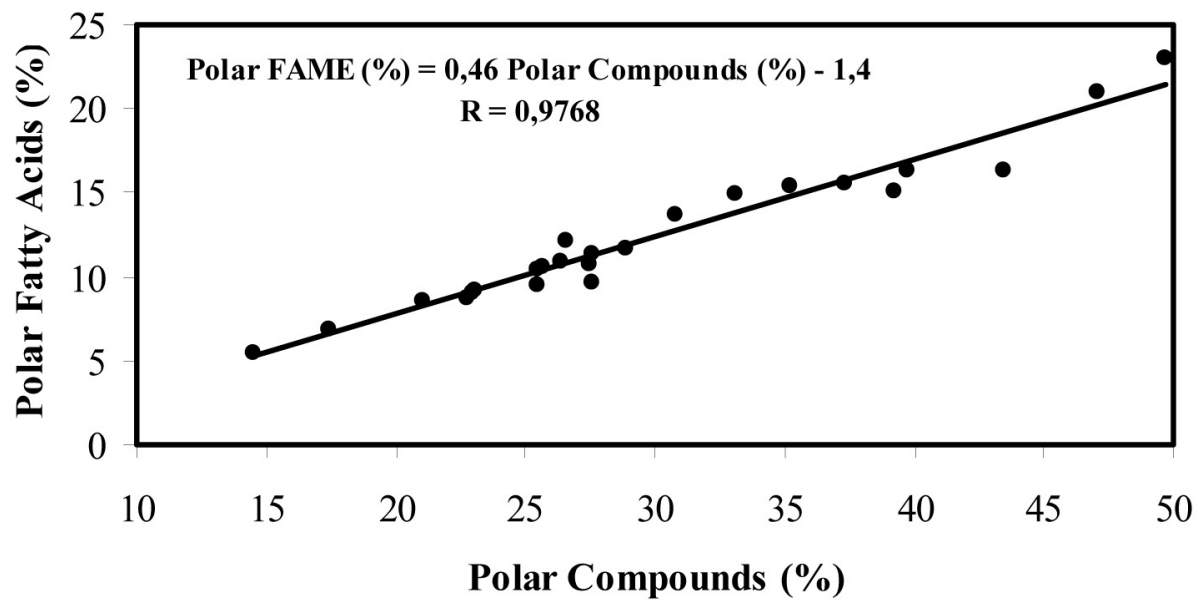

Figure 2

Linear regression between polar compounds and polar fatty acid methyl esters. 
FAME, originally TG-bound aldehydes and acids resulting from hydroperoxide breakdown, are the most representative compounds (Márquez Ruiz and Dobarganes, 1996; Velasco et al., 2005) Concerning oxidized compounds of molecular weight similar to that of the starting fatty acids, the main groups present corresponded to epoxyacids, ketoacids and hydroxyacids (Velasco et al., 2004).

Figure 3 shows a chromatogram of used sunflower frying oil. The zone corresponding to retention times including $\mathrm{C} 22: 0$ and $\mathrm{C} 24: 0$ has been widened to observe the differences between FAME obtained from a refined sunflower oil and from the same oil used in frying until the rejection limit $(25 \%)$. The oxidized fatty acids formed and eluting would be included in the ester content given by the standard method and may suppose an overestimation between 1 and $2 \%$.

Interferences from monomeric and polymeric FAME can be also found in the application of the standard method (European Standard, 2003b) where a high temperature is applied for the elution of TG and partial glycerides. Studies on this point are being carried out and the results will be reported shortly .

\section{CONCLUSIONS}

a) The determination of polar fatty acids in biodiesels allows for the exact determination of non-polar esters and is an interesting alternative to the GC standard method due to its accuracy and to the fact that no instrumental techniques are required.

b) From the percentage of polar compounds in used frying fats and oils, the percentage of nonpolar and polar methyl esters after the production of biodiesel can be roughly deduced given the excellent correlation between both determinations. c) Compounds from polar FAME could be present in the chromatograms obtained from present techniques for the quality evaluation of biodiesel when used frying fats and oils are used for biodiesel production.

\section{ACKNOWLEDGEMENT}

This research work was supported by Junta de Andalucía and MCYT (Project AGL 2004-00148). The authors thanks Ms Mercedes Giménez for assistance.

\section{BIBLIOGRAPHY}

Al-Widyan M, Al-Shyoukh A. 2002. Experimental evaluation of the transesterification of waste palm oil into biodiesel. Bioresour. Technol. 85, 253-256.

Al-Widyan M, Tashtoush G, Abu-Qudais M. 2002. Utilization of ethyl ester of waste vegetable oils as fuel in diesel engines. Fuel Process. Technol. 76, 91-103.

Costa Neto PR, Rossi L, Zagonel G, Ramos L. 2000. Produção de Biocombustível Alternativo ao Óleo Diesel Através da Transesterificação de Óleo de Soja Usado em Frituras. Quim. Nova 23, 531-537.

Dobarganes MC, Márquez Ruiz G. 1995a. Calidad de las grasas de fritura en el sector de restauración de Andalucía. Grasas y Aceites 46, 115-120.

Dobarganes MC, Márquez Ruiz G. 1995b. Control de calidad de las grasas de fritura. Validez de los métodos de ensayos rápidos en sustitución de la determinación de compuestos polares. Grasas $y$ Aceites 46, 196-201.

Dobarganes MC, Márquez Ruiz G. 1998. Regulation of used frying fats and validity of quick tests for discarding the fats. Grasas y Aceites 49: 331-335.

Dobarganes MC, Márquez Ruiz G. 2006. Formation and analysis of oxidized monomeric, dimeric and higher oligomeric triglycerides. In Deep Frying: Chemistry Nutrition and Practical Applications. $2^{\text {nd }}$ edition. Ed. by M.D. Erickson. American Oil Chemists' Society, (Champaign, Illinois), pp 87-110.

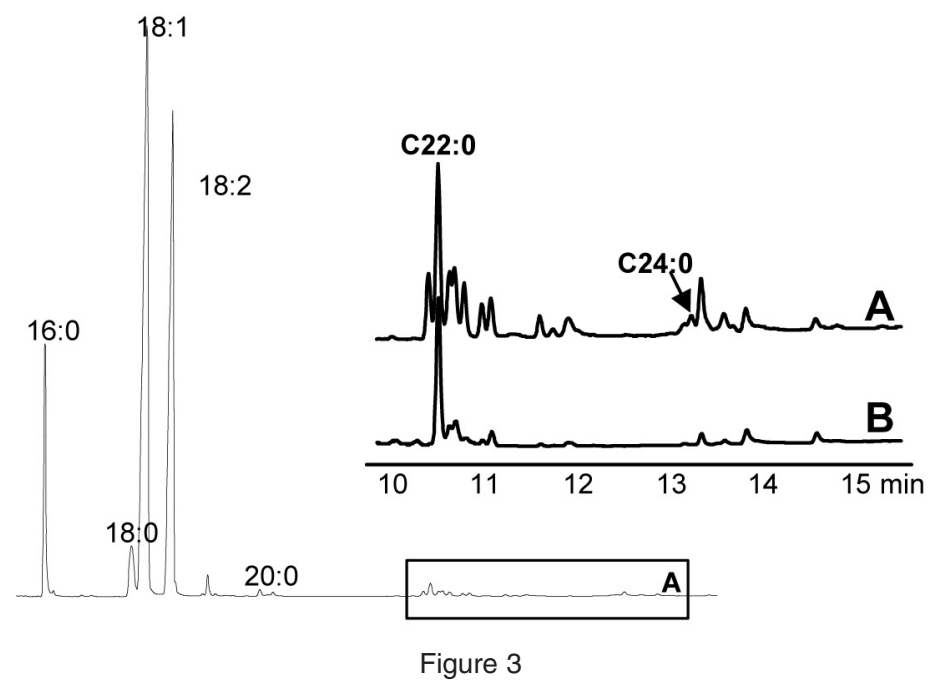

Chromatogram corresponding to the fatty acid methyl esters of used frying sunflower oil and significant part showing the differences between $(A)$ used frying sunflower oil and (B) initial sunflower oil. 
Dobarganes MC, Pérez-Camino MC, Gutiérrez González-Quijano R. 1984. Métodos analíticos de aplicación en grasas calentadas. I. Determinación de ésteres metílicos no alterados. Grasas y Aceites 35, 172-177.

Dobarganes MC, Pérez-Camino MC, Márquez Ruiz G. 1988. High performance size exclusion chromatography of polar compounds in heated and non-heated fats. Fat Sci. Technol. 90, 308-311

Dobarganes MC, Velasco J, Dieffenbacher A. 2000. The determination of polar compounds, polymerised triacylglycerols, oxidised triacylglycerols and diacylglycerols in fats and oils. Pure App. Chem. 72, 1563-1575.

Dorado MP, Ballesteros E, Arnal JM, Gómez J, López FJ. 2003. Exhaust emissions from a diesel engine fuelled with transesterified waste olive oil. Fuel $\mathbf{8 2}$, 1311-1315

European Standard EN 14103. 2003a. Fat and oil derivatives - fatty acid methyl esters (FAME) - determination of ester and linolenic acid methyl ester contents. European Committee for Standardization, Brussels, Belgium.

European Standard EN14105. 2003b. Fat and oil derivatives Fatty Acid Methyl Esters (FAME) Determination of free and total glycerol and mono-, di-, and triglyceride contents. European Committee for Standardization, Brussels, Belgium.

Felizardo P, Neiva Correia MJ, Raposo I, Mendes JF, Berkemeier R, Moura Bordado J. 2006. Production of biodiesel from waste frying oils. Waste Management 26, 487-494

Firestone D. 1996. Regulation of frying fats and oils. In: Deep Frying: Chemistry, Nutrition and Practical Applications, chap. 19, 323-334. Ed: Perkins E.G., Erickson M.D., AOCS Press, Champaign, Illinois.

González Gómez ME, Howard-Hildige R, Leahy JJ, Rice B. 2002.Winterization of waste cooking oil methyl ester to improve cold temperature fuel properties. Fuel 81, 33-39.

IUPAC. 1992. Standard Methods for the Analysis of Oils, Fats and Derivatives. Standard Method 2.507International Union of Pure and Applied Chemistry. 1st supplement to 7th edition, Pergamon Press, Oxford.

Leung DYC. 2001. Development of a clean biodiesel fuel in Hong Kong using recycled oil. Water Air Soil Poll. 130, 277-282.

Leung DYC, Guo Y. 2006. Transesterification of neat and used frying oil: Optimization for biodiesel production. Fuel Processing Technol. 87, 883-890.

Marmesat S, Rodrigues Machado E, Velasco J Dobarganes MC. 2007. Used frying fats and oils: comparison of rapid tests based on chemical and physical oil properties. Int. J. Food Sci.Technol. 42, 601-608.

Márquez Ruiz G, Pérez-Camino MC, Dobarganes MC. 1990. Combination of adsorption and size-exclusion chromatography for the determination of fatty acid monomers, dimers and polymers. J. Chromatog. 514, $37-44$
Márquez-Ruíz G, Dobarganes MC. 1996. Short-chain acid formation during thermoxidation and frying. $J$. Sci. Food Agric. 70, 120-126

Márquez-Ruíz G, Tasioula-Margari M, and Dobarganes MC. 1995. Quantitation and Distribution of altered fatty acids in frying fats. J. Am. Oil Chem. Soc. 72, 1171-1176.

Mittelbach M, Tritthart P. 1988. Diesel fuel derived from vegetable oils, III. Emission tests using methyl esters of used frying oil. J. Am. Oil Chem. Soc. 65, 1185-1187.

Rodrigues Machado E, Marmesat S, Abrantes S, Dobarganes MC. 2007. Uncontrolled variables in frying studies: differences in repeatability between thermoxidation and frying experiments. Grasas $y$ Aceites 58, 283-288.

Schober S, Seidl I, Mittelbach M. 2006 Ester content evaluation in biodiesel from animal fats and lauric oils. Eur. J. Lipid Sci. Technol. 108, 309-314.

Supple B, Howard-Hildige R, Gonzalez-Gomez E, Leahy JJ. 2002. The effect of steam treating waste cooking oil on the yield of methyl ester, J. Am. Oil Chem. Soc. 79, 174-178.

Tashtoush G, Al-Widyan M, Al-Jarrah M. 2004. Experimental study on evaluation and optimization of convertion of waste animal fat into biodiesel, Energy Conv. Manage. 45: 2697-2711

Tomasevic AV, Siler-Marinkovic SS. 2003. Methanolysis of used frying oil, Fuel Process. Technol. 81: 1-6.

Ulusoy Y, Tekin Y, Cetinkaya M, Karaosmanoglu F. 2004. The engine tests of biodiesel from used frying oil, Energy Sources 26: 927-932.

Varela G. 1985. Current facts about the frying of Foods.In: Frying of Foods, chap. 1, 9-25. Ed: Varela G., Bender A.E., Morton, I.D., VCH Chichester, England.

Velasco J, Marmesat M, Márquez-Ruiz $G$ and Dobarganes MC. 2004. Formation of short-chain glycerol-bound oxidation compounds and oxidised monomeric triacylglycerols during deep-frying and occurrence in used frying fats. Eur. J. Lipid Sci. Technol. 106, 728-735.

Velasco J, Marmesat S, Bordeaux O, Márquez-Ruiz G, Dobarganes MC. 2005. Quantitation of short-chain glycerol-bound compounds in thermoxidized and used frying oils.A monitoring study during thermoxidation of olive and sunflower oils. J. Agr. Food Chem. 53, 4006-4011.

Zaher F. 2003. Utilization of used frying oil as diesel engine fuel, Energy Sources 25, 819-826.

Zhang Y, Dubé MA, McLean DD, Kates M. 2003a. Biodiesel production from waste cooking oil: 1. Process design and technological assessment, Bioresource Technol. 89, 1-6.

Zhang Y, Dubé MA, McLean DD, Kates M. 2003b. Biodiesel production from waste cooking oil: 2 . economic assessment and sensitivity analysis, Bioresource Technol. 90, 229-240

Recibido: 26/09/07 Aceptado: 19/11/07 